\title{
CHRONIC MIELOMONOSITIC LEUKEMIA PADA USIA MUDA
}

Rangga Lunesia1 ${ }^{1}$ Irza Wahid²

\begin{abstract}
Abstrak
Chronic Mielomonositic Leukemia (CMML) adalah keganasan heterogen yang ditandai dengan monositosis di darah perifer (>1×109/L), terdapat kelainan mielodisplastik dan mieloproliferatif di sumsum tulang, dan memiliki kecendrungan untuk bertransformasi menjadi leukemia myeloid akut. Angka kejadian CMML sangat jarang, di Indonesia tercatat hanya $2,5 \%$ kasus dari keseluruhan MDS. Pengobatan pada MP-CMML dengan jumlah blast sedikit adalah pemberian terapi sitoreduktif yaitu hydroxyurea yang bertujuan mengontrol proliferasi myelomonositic sel dan mengurangi organomegali. Telah dilaporkan suatu kasus laki-laki 28 tahun dengan keluhan pucat. Pada pemeriksaan fisik ditemukan konjungtiva anemis dan splenomegali. Pemeriksaan laboratorium didapatkan hemoglobin $6.5 \mathrm{gr} / \mathrm{dl}$, leukosit: 93.540/mm3, hitung jenis: 1/0/6/42/8/27. Pemeriksaan BMP menunjukkan aktivitas Granulopoeitik: meningkat, ditemukan mieloblast $3 \%$, Promielosit $3 \%$, monoblast $2 \%$, Promonosit $1 \%$, dominasi monosit $33 \%$, ditemukan juga dysplasia seperti pseudo pelgerhuet, dengan kesan sesuai gambaran Chronic Mielomonositic Leukemia. Pada pasien ini dengan jumlah leukosit $>13 \times 10^{9} / \mathrm{L}$ termasuk kedalam MP-CMML diberikan terapi hydroxyurea. Follow up setelah pemberian terapi $\mathrm{Hb} 8.8 \mathrm{gr} / \mathrm{dl}$, Leukosit 38.200/mm³, pada hitung jenis: 0/1/5/45/7/23.
\end{abstract}

Kata kunci: Chronic Mielomonositic Leukemia, hydroxyurea.

\begin{abstract}
Chronic Mielomonositic Leukemia (CMML) is a heterogeneous malignancy characterized by monocytosis in peripheral blood (> 1x109 / L), there are myelodysplastic and myeloproliferative abnormalities in the bone marrow, and have a tendency to transform into acute myeloid leukemia. The incidence of CMML is very rare, in Indonesia only $2.5 \%$ of all MDS cases were recorded. Treatment of MP-CMML with a small amount of blast is the provision of cytoreductive therapy, namely hydroxyurea which aims to control the proliferation of cell myelomonositic and reduce organomegaly. A 28-year-old male with pale complaints was reported. Physical examination revealed anemic conjunctivae and splenomegaly. Laboratory tests found hemoglobin $6.5 \mathrm{~g} / \mathrm{dl}$, leukocytes: $93.540 / \mathrm{mm} 3$, count type: 1/0/6/42/8/27. BMP examination showed Granulopoeitic activity: increased, found 3\% mieloblasts, Promielocytes 3\%, monoblasts $2 \%$, Promonocytes $1 \%$, dominance of monocytes $33 \%$, also found dysplasia such as pseudo pelgerhuet, with the impression according to the description of Mielomonositic Chronic Leukemia. In these patients with leukocyte counts> $13 \times 109$ / L included in MP-CMML, given hydroxyurea therapy. Follow-up after treatment of Hb 8.8 gr / dl, Leukocytes 38, $200 / \mathrm{mm} 3$, on count type: 0/1/5/45/7/23
\end{abstract}

Keywords: Chronic Mielomonositic Leukemia, hydroxyurea.

Affiliasi penulis : 1. Program Studi Pendidikan Profesi Dokter Spesialis-1 IImu Penyakit Dalam FK Unand/RSUP M Djamil Padang 2. Subbagian Hemato Onkologi Medis Bagian IImu Penyakit Dalam FK Unand/RSUP M Djamil Padang.

Korespondensi : pibipd@yahoo.com Telp: 0751-37771

\section{PENDAHULUAN}

Chronic Myelomonocytic Leukemia (CMML) adalah kelainan stem cell hematopoietik klonal yang ditandai oleh keadaan overlap myelodysplastic syndromes (MDS) dan myeloproliferative neoplasms (MPN). CMML adalah keganasan heterogen yang ditandai dengan monositosis di darah perifer $\left(>1 \times 10^{9} / \mathrm{L}\right)$, terdapat kelainan mielodisplastik dan mieloproliferativ di sumsum tulang, dan memiliki kecendrungan untuk bertransformasi menjadi leukemia myeloid akut. 1,2

Angka kejadian CMML $10 \%$ dari seluruh kasus sindrom mielodisplastik .Usia saat didiagnosis rata-rata adalah 65-75 tahun, dengan perbandingan pria dan wanita 1,5-3:1. Insiden pasti CMML tidak diketahui, namun diperkirakan 4 kasus per 100.000 orang per tahun. Distribusi nya berdasarkan data di Negara barat sekitar $10 \%$, di Indonesia sendiri tercatat sebanyak $2,5 \%$ dari seluruh sindrom mielodisplastik. ${ }^{2}$ Penyebab CMML adalah terjadinya kelainan klonal sitogenetik yang terjadi pada $20-30 \%$, dimana $>90 \%$ pasien mengalami mutasi gen. Mutasi melibatkan TET2 (60\%), SRSF2 (50\%), ASXL1 (40\%), dan RAS $(30 \%) \cdot{ }^{3,4}$

Pada tahun 1982, FAB (French American British group) membuat klasifikasi khusus untuk sindrom mielodisplastik yang diterima secara luas sampai saat ini. FAB membagi MDS menjadi 5 kategori berdasarkan jumlah blast dalam darah tepi, sumsum tulang, jumlah monosit dalam darah tepi, serta jumlah ringed sideroblast dalam sumsum tulang. Klasifikasinya terdiri atas : Refractory anemia (RA), Refractory anemia with ringed sideroblast (RARS), Refractory anemia with Excess Blast (RAEB), Refractory anemia with excess blast transformation (RAEB), Chronic mielomonositic leukemia (CMML), sedangkan CMML dibagi menjadi 2 : CMML-1 (blast 
$<5 \%$ di sirkulasi dan $<10 \%$ di sumsum tulang), CMML2 (blast $5-19 \%$ di sirkulasi dan $10-19 \%$ di sumsum tulang atau terdapat Auer Rod di luar jumlah blast). ${ }^{5}$

Kriteria diagnosis CMML : Monosit darah perifer > 1x10\%/L, blast dan premonosit 5-20\% di darah perifer dan/atau sumsum tulang, tidak adanya kromosom Philadelphia atau fusi onkogen BCR-ABL1, displasia yang melibatkan satu atau lebih garis keturunan myeloid. Jika myelodysplasia tidak ada atau minimal, diagnosis CMML masih bisa dibuat jika kriteria lainnya terpenuhi dan terdapat kelainan genetik klonal atau molekuler dalam sel hematopoietik atau jika monositosis bertahan selama minimal 3 bulan dan penyebab lain dari monositosis telah dieksklusi ${ }^{3,7}$

Flow cytometry pada pasien CMML menunjukkan peningkatan fraksi monosit klasik (CD14 ${ }^{+} /$CD16 $\left.^{-}\right)$, dengan spesifisitas $95,1 \%$ dan sensitivitas $91,9 \%$. Tidak ada temuan patognomonis pada CMML. Biopsi sumsum tulang sering ditemukan hiperseluler dengan hiperplasia dan displasia granulositik. Hampir $80 \%$ pasien menunjukkan mikromegakariosit dengan permukan dan lobus nuklear yang abnormal. Dapat juga ditemukan proliferasi monositik, akan tetapi sangat sulit ditemukan pada aspirasi atau biopsi. ${ }^{3}$

Pada immunophenotyping sel sumsum tulang abnormal sering menunjukkan antigen mielomonositik seperti, CD13, CD33, dengan ekspresi variabel CD14, CD68, dan CD64. Tidak ada kelainan sitogenik yang patognomonis pada CMML. Abnormalitas klonal sitogenetik ditemukan pada $20-30 \%$ pasien CMML. Alterasi paling umum yaitu trisomi $8,-\mathrm{Y}$, abnormalitas kromosom 7, trisomi 21, dan kariotipe kompleks. 5,7

Pada pemeriksaan darah ditemukannya monositosis, peningkatan leukosit, terdapat disgranulopoiesis, promonosit, blast, dan prekursor netrofil. Aspirasi sumsum tulang, terdapat displasia dalam satu atau lebih garis turunan myeloid, hiperplasia granulositik, blast, dan harus mencakup mieoblast, monoblast, dan promonosit. ${ }^{7}$

Penatalaksanaan CMML dapat diberikan dengan supportive care. Perawatan suportif fokus pada manajemen gejala/paliatif dan dilakukan pada pasien diantaranya mempertahankan kadar hemoglobin yang optimal, menangani komplikasi yang disebabkan oleh trombositopenia atau neutropenia berat. Allogeneic stem cell transplantation merupakan satu-satunya pilihan kuratif untuk pasien CMML. Teknik ini penuh dengan komplikasi, seperti penolakan, non-relaps mortality (NRM), graft-versushost-disease (GVHD) akut dan kronis (GVHD), kerusakan organ dan relaps pada periode pasca transplantasi. ${ }^{3}$

Pada pasien berusia muda dengan resiko tinggi, nilai prognostik buruk, kariotipe resiko tinggi dan peningkatan blast pada sumsum tulang, transplantasi stem cell awal harus dipertimbangkan. Pada usia lanjut, tidak memenuhi syarat transplantasi, dan pasien dengan donor terbatas, penggunaan agen hipometilate off-label dengan terapi suportif harus dipertimbangkan ${ }^{3}$

Prognosis CMML bervariasi, dengan kelangsungan hidup rata-rata 2,5 tahun. Salah satu indikator terpenting pada CMML adalah jumlah blast. CMML-1 memiliki peluang $18 \%$ bertransformasi menjadi AML dalam 5 tahun, sedangkan CMML-2 memiliki resiko $63 \%$ menjadi AML dalam 5 tahun. 4,6

\section{LAPORAN KASUS}

Seorang pasien laki-laki 28 tahun datang dengan keluhan pucat yang dirasakan sejak 1 minggu sebelum masuk rumah sakit. Gusi berdarah dialami 3 hari yang lalu, penurunan berat badan ada sebanyak 5 kg selama 1 bulan ini. Pasien didiagnosa di RS sebelumnya dengan anemia dan suspek leukemia, sudah dilakukan transfusi darah merah sebanyak 3 kantong, kemudian pasien dirujuk ke RSUP dr M Djamil Padang untuk pemeriksaan dan tatalaksana selanjutnya.

Pasien kemudian dirawat di bangsal bagian penyakit dalam RSUP dr M. Djamil Padang. Pada pemeriksaan fisik ditemukan konjungtiva anemis dan splenomegali. Pasien lalu direncanakan pemeriksaan laboratorium hematologi lengkap. Hasil dari pemeriksaan laboratorium didapatkan hemoglobin 6.5 gr/dl, leukosit: 93.540/mm3, trombosit: $209.000 / \mathrm{mm} 3$, hitung jenis: $1 / 0 / 6 / 42 / 8 / 27$, dominasi sel monosit: $27 \%$, Blast 5\%, Mielosit 7\% dan Metamielosit 4\%, gambaran darah tepi ditemukan gambaran anemia normositik normokrom dengan leukositosis dengan blast $5 \%$.

Pemeriksaan BMP menunjukkan aktivitas Granulopoeitik: meningkat, ditemukan mieloblast 3\%, Promielosit 3\%, monoblast 2\%, Promonosit 1\%, dominasi monosit $33 \%$, ditemukan juga dysplasia seperti pseudo pelgerhuet, dengan kesan sesuai gambaran Chronic Mielomonositic Leukemia. Pada pasien ini dengan jumlah leukosit $>13 \times 10 \% / L$ termasuk kedalam MP-CMML

Tatalaksana pada pasien ini diberikan terapi suportif yaitu transfusi PRC dan transfusi trombosit serta terapi hydroxyurea. Follow up setelah pemberian terapi hydroxyurea adalah $\mathrm{Hb} 8.8 \mathrm{gr} / \mathrm{dl}$, Leukosit $38.200 / \mathrm{mm}^{3}$, Trombosit $167.000 / \mathrm{mm} 3$, dan hematokrit $23 \%$ pada hitung jenis: 0/1/5/45/7/23.

\section{PEMBAHASAN}

Telah dirawat pasien laki-laki usia 28 tahun dengan diagnosis akhir Mielodysplasia syndrome (MDS) tipe chronic mielomonositic leukemia. Diagnosis ini ditegakkan berdasarkan anamnesis, pemeriksaan fisik, laboratorium dan pemeriksaan penunjang lainnya. Kasus ini menjadi menarik karena berdasarkan data epidemiologi MDS sering terjadi pada usia lanjut dengan $80 \%$ kasus berumur diatas 60 tahun. Pada kasus ini pasien berumur 28 tahun. Williamson et al melaporkan insiden MDS pada kelompok umur $<50$ tahun yaitu $0,5 / 100.000 /$ tahun. ${ }^{8}$ 
Data-data gejala klinis kasus ini sesuai penelitian Schumacher dan Nand melaporkan bahwa $90 \%$ kasus MDS bersifat simptomatik pada saat dijumpai pertama kali. Simptom yang paling sering adalah rasa lelah (87\%), berat badan menurun $(29 \%)$, demam (24\%), dan perdarahan (24\%). Spenomegali adalah gejala klinis yang cukup sering dijumpai sektar $25 \%$ pada kasus CMML. ${ }^{9}$

Berdasarkan hasil BMP pada pasien ini didapatkan kesan aktivitas sistem eritropoeitik tertekan, aktivitas granulopoietik meningkat yang didominasi oleh monosit sebanyak $33 \%$ dengan gambaran disgranulopoietik dengan adanya pseudo pelgerhuet sehingga dikategorikan sebagai Chronic Mielomonositik leukemia menurut FAB (french American British Group). ${ }^{5}$

Namun berdasarkan kriteria WHO untuk MDS, hal ini masih menjadi perdebatan dalam memasukan CMML kedalam kriteria MDS karena walaupun terjadi tanda dysplasia, tetapi lebih sering menunjukkan tanda mieloproliferatif, splenomegali dan leukositosis sehingga lebih tepat dimasukan kedalam MPD (myeloproliferatif disorders), berdasarkan update WHO 2016 CMML didefenisikan sebagai kelainan hematopoetik klonal yang ditandai oleh keadaan overlap myelodysplasia sindrom (MDS) dan myeloproliferative neoplasma. ${ }^{1,2}$

Pasien pada awalnya didiagnosis banding dengan leukemia mielositik kronis karena adanya leukositosis (monositosis) dan splenomegali, namun kemudian setelah dilakukan BMP diagnosis leukemia bisa disingkirkan dengan ditemukan adanya gambaran CMML. Menurut Bennet JM et al pada kasus yang meragukan pemeriksaan sitogenetika dan pemeriksaan bcr abl dapat membantu membedakan leukemia dengan CMML. ${ }^{5}$

Penatalaksaan pada pasien ini dilakukan terapi suportif yaitu transfusi PRC dan transfusi trombosit. menurut Hoffbrand dan Moss, MDS dibagi menjadi dua kelompok yaitu high risk dan low risk MDS, pada CMML termasuk kedalam High risk MDS dengan ditemukannya blast sumsum tulang $5 \%$ atau lebih yang dapat dipertimbangkan pemberian kemoterapi, baik tunggal maupun intensif disamping terapi suportif. 10

Untuk penderita berumur kurang dari 50 tahun Stem Cell Transplantation merupakan satusatunya pengobatan yang dapat memungkinkan kesembuhan pada pasien. Kemoterapi yang telah dicobakan pemberian cytarabine dosis rendah tetapi pada penelitian ECOG yang dilakukan pada 140 penderita didapatkan data $4 \%$ yang mengalami remisi komplit dan $15 \%$ penderita yang menggunakan cytarabine mengalami komplikasi sepsis yang berat. Penggunaan Azacytidine juga sudah banyak dilakukan tetapi hasilnya tidak terlalu menggembirakan. ${ }^{3}$

Prognosis pada MDS sangat bervariasi. Banyak faktor yang terkait dengan prognosis dan harapan hidup yaitu klasifikasi FAB, umur, jenis kelamin, kadar hemoglobin, jumlah netrofil, jumlah trombosit, jumlah monosit, adanya sel muda (blast) dalam sirkulasi, perubahan displastik dari sumsum tulang, persentase sel blast dalam sumsum tulang, sitogenetik dan sebagainya. Prognosis pada pasien ini berdasarkan umur baik karena berada pada usia muda, berdasarkan parameter darah tepi pada kasus CMML dengan leukositosis menunjukan prognosis yang jelek, parameter sumsum tulang CMML mempunyai survival yang jauh lebih jelek jika dibandingkan dengan RAEB karena pada CMML memiliki jumlah blast yang jauh lebih banyak. Angka harapan hidup pada penderita CMML hanya sekitar 18 bulan namun dari berbagai penelitian didapatkan nilai prognsotik paling konsisten adalah jumlah sel blast dalam sumsum tulang. MDS dengan sel blast dalam sumsum tulang $>5 \%$ mempunyai survival lebih pendek dibandingkan dengan MDS yang memiliki blast $>5 \%{ }^{6}$

\section{SIMPULAN}

Dilaporkan suatu kasus jarang pada usia muda yakni pasien laki-laki 28 tahun, dengan diagnosis Chronic Mielomonositic Leukemia. Terapi berupa hydroxyurea memberikan hasil yang baik. Prognosis pada pasien ini berdasarkan umur baik karena berada pada usia muda tetapi berdasarkan parameter darah tepi pada kasus CMML dengan leukositosis menunjukan prognosis yang jelek, parameter sumsum tulang CMML mempunyai survival yang jauh lebih jelek jika dibandingkan dengan RAEB karena pada CMML memiliki jumlah blast yang jauh lebih banyak.

\section{DAFTAR PUSTAKA}

1. Patnaik MM, Lasho TL, Finke CM, Hanson CA, Hodnefield JM, Knudson CL et al. Spliceosome mutations involving SRSF2, SF3B1, and U2AF35 in chronic myelomonocytic leukemia: Prevalence, clinical correlates, adn prognostic relevance. American J Haematol. 2013;88(3):201-206.

2. Bakta IM. Hematologi klinik ringkas. EGC. 2015;178-185.

3. Patnaik MM, Tefferi A. Chronic Myelomonocytic Leukemia: Update on Diagnosis, Risk Stratification, and Management. American J Haematol. 2018;93(6):824-840.

4. Padron E, Garcia- Manero G, Patnaik MM, Itzykson R, Lasho T, Nazha A et al. An international data set for CMML validates prognostic scoring systems and demonstrates a need for novel prognostication strategies. Blood Cancer Journal. 2015;5(7):1-8.

5. Bennett JM, Catovsky D, Daniel MT, Flandrin G, Galton DA, Gralnick HR, et al. Proposals for the classification of the myelodysplastic syndromes : French-American-British (FAB) 
co-operative group. British journal haematology. 1982;51:189-199.

6. Ades L, Sekeres MA, Wolfromm A, Teichman ML, Tiu RV, List AF et al. Predictive factors of response and survival among chronic myelomonocytic leukemia patients treated with azacitidine. Leukemia Research. 2013;37(6):609-613.

7. Benton CB, Nazha A, Pemmaraju N, GarciaManero G. Chronic myelomonocytic leukemia. Crit rev oncol haematol. 2015;95(2):222-242.

8. Williamson PJ, Kruger AR, Reynolds PJ, Hamblin TJ, Oscier DG. Establishing the incidence of myelodysplastic syndrome. British J Haematol. 1994;87:743745.

9. Schumacher HR, Nand S. Myelodysplastic syndromes: Approach to diagnosis and treat ment. New York: Igaku-Shoin medical publisher. 1995;105:595-598.

10. Hoffbrand V, Moss PAH. Essential haematology. Wiley Blackwell. 2016;7(1):177186. 